\title{
SMALL EARLY MIOCENE LISTRIODONT SUID (ARTIODACTYLA: MAMMALIA) FROM SABUNCUBELI (MANISA, SW ANATOLIA), TURKEY
}

\author{
MARTIN PICKFORD ${ }^{1, *}$, TANJU KAYA ${ }^{2}$, ERHAN TARHAN ${ }^{3}$, DERYA ERYLMAZ ${ }^{4}$, SERDAR MAYDA ${ }^{5}$ \\ ${ }^{1}$ UMR 7207 CR2P - MNHN-CNRS-SU, Muséum national d'Histoire naturelle, Paris, France; e-mail: martin.pickford@mnhn.fr. \\ 2 Ege University Faculty of Science, Izmir, Turkey; e-mail: tanju.kaya@ege.edu.tr. \\ ${ }^{3}$ Department of Anthropology, Faculty of Art and Sciences, Hittite University, Çorum, Turkey; e-mail: erhantarhannn@gmail.com. \\ ${ }^{4}$ Mehmet Akif Ersoy University, Department of Anthropology, Burdur, Turkey. \\ ${ }^{5}$ Ege University Faculty of Science, Biology Department, Bornova-Izmir, Turkey; e-mail: serdar.mayda@ege.edu.tr. \\ * corresponding author
}

Pickford, M., Kaya, T., Tarhan, E., Erylmaz, D., Mayda, S. (2020): Small early Miocene listriodont suid (Artiodactyla: Mammalia) from Sabuncubeli (Manisa, SW Anatolia), Turkey. - Fossil Imprint, 76(2): 325-337, Praha. ISSN 2533-4050 (print), ISSN 2533-4069 (on-line).

\begin{abstract}
Turkey is known for the wealth of fossil suids found in deposits of middle Miocene, late Miocene and Plio-Pleistocene levels but material of this family from early Miocene and Palaeogene deposits is rare in the country, one of the few published occurrences being from Şemsettin (Kumartaş Formation, MN 4, Çankiri-Çorum Basin). For this reason, it is interesting to record the presence of small suid remains in the Soma Formation at Sabuncubeli (Manisa, SW Anatolia) in deposits correlated to MN 3 (early Miocene) and thus the earliest known Turkish members of the family. The upper and lower teeth are herein attributed to a new genus and species (Prolistriodon smyrnensis) of Listriodontinae because, in a nascent way, they show a suite of derived morphological features such as upper central incisors with apical sulci, and upper molars with lingual precrista, found in listriodonts but not in Kubanochoerinae, Palaeochoerinae, Tetracondontinae, Hyotheriinae, Namachoerinae, Cainochoerinae or Suinae.
\end{abstract}

Key words: Suidae, Turkey, early Miocene, Artiodactyla, Listriodontinae, Prolistriodon smyrnensis gen. et sp. nov., derived characters, folivory, omnivory

Received: June 21, 2020 | Accepted: September 9, 2020 | Issued: December 30, 2020

\section{Introduction}

Turkey is endowed with a great variety of fossil suids which have been collected from middle Miocene, late Miocene, Plio-Pleistocene and Recent deposits (Malik and Nafiz 1933, Tschachtli 1942, Thenius 1949, Senyürek 1951, 1952, Ozansoy 1965, Hünermann 1975, Pickford and Ertürk 1979, Fortelius and Bernor 1990, Fortelius et al. 1996, Van der Made and Tuna 1999, Van der Made 2003, Geraads et al. 2005, Liu et al. 2005, Yakut 2012, Bartosiewicz et al. 2013, Van der Made et al. 2013, Kostopoulos and Sen 2016, Pickford 2016a). In contrast, remains of this family of artiodactyls from Turkish early Miocene and Palaeogene deposits are few and far between, one of the rare described occurrences being from Şemsettin (Kumartaş Formation, MN 4, Çankiri-Çorum Basin) (Orliac et al. 2015).

Between 2000 and 2004, while screening for small mammals at Sabuncubeli in deposits mapped as Soma Formation (de Bruijn et al. 2006, Kaya et al. 2007), SM recovered several specimens of medium-sized mammals, including the suid teeth described herein. An important point about the collection is that it contains upper and lower incisors as well as canines and some cheek teeth. There are also two deciduous teeth in the sample. The dental representation is useful because among early Miocene bunodont suoids (and suids in general), the incisors and canines are often more diagnostic than molars for systematic purposes. On the basis of the incisors, it is clear that the suid teeth from Sabuncubeli do not belong to Hyotheriinae, large Kubanochoerinae, Tetraconodontinae, Namachoerinae, Cainochoerinae or Suinae, and their canine morphology excludes any possibility that they might belong to Doliochoeridae, Siderochoeridae, Schizoporcidae or Sanitheriidae (Pickford 2016a, b, 2017, 2018b, Pickford and Tsujikawa 2019). The Sabuncubeli anterior teeth indicate close affinities to Palaeochoerinae (sensu Pickford 2018b) in particular the genus Palaeochoerus, but some of the incisors possess features that recall Listriodontinae (in miniature) and this adds to the interest in the fossils. There are also some features in the cheek teeth that resemble, in miniature, 


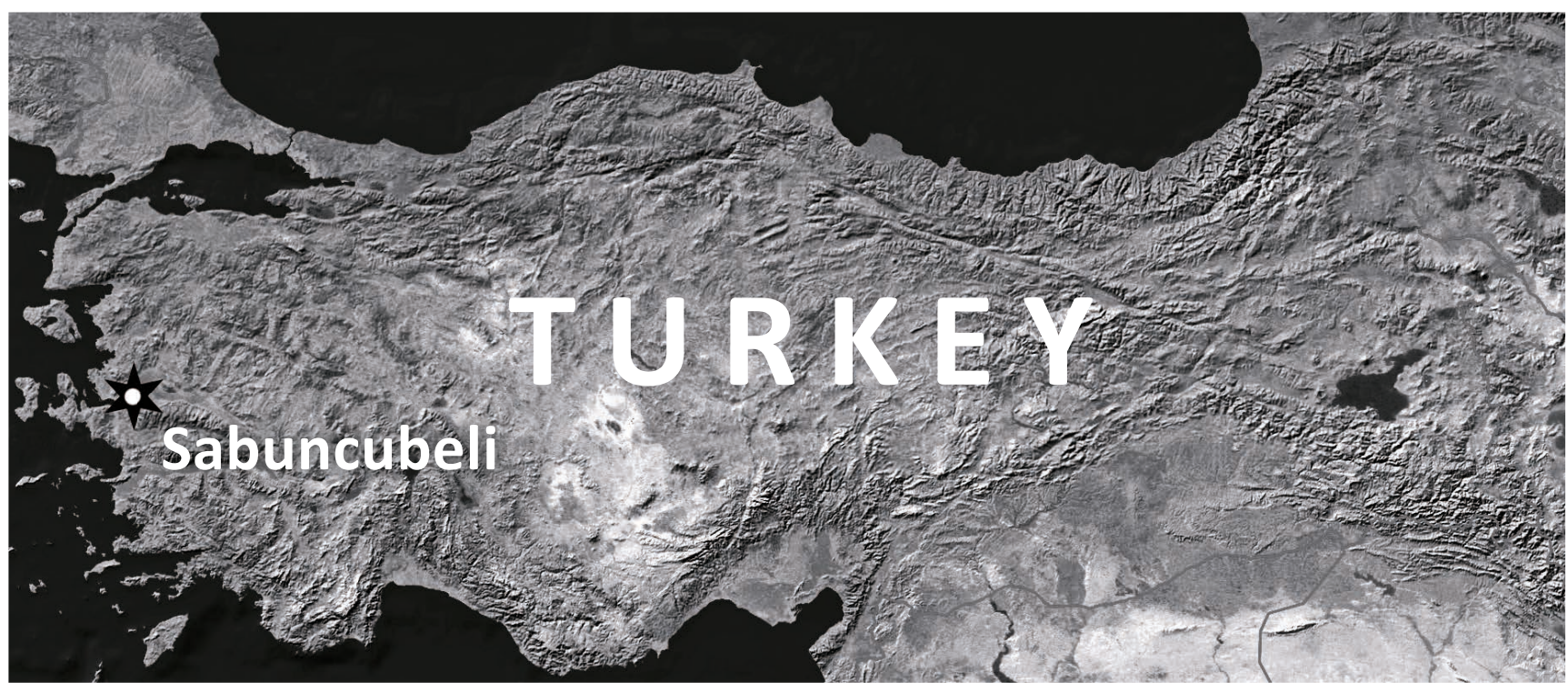

Text-fig. 1. Map of Turkey showing the location of the early Miocene fossil site of Sabuncubeli, close to Izmir.

the teeth of Listriodon retamaensis from Spain (Pickford and Morales 2003, 2016).

Currently, the specimens from Sabuncubeli (MN 3 basal part) are the oldest suids known from Turkey, being somewhat older than a sample from Şemsettin (MN 4) described by Orliac et al. (2015), and tentatively attributed by these authors to the African genus Nguruwe PicKFord, 1986, as the new species Nguruwe? galaticum. The same authors attributed an isolated suid $\mathrm{d} / 4$ from Şemsettin to Hyotheriinae Cope, 1888, as genus and species indet. The latter tooth possesses a root beneath the protoconid, so it is definitely from a suid rather than from a doliochoerid or siderochoerid (Pickford 2018a).

The aim of this note is to describe and interpret the Sabuncubeli suid collection. It is concluded that the sample is homogeneous and represents a single species, herein called Prolistriodon smyrnensis gen. et sp. nov.

\section{Geological and palaeontological context}

The geological and faunal contexts of the Sabuncubeli fossils were described by Kaya et al. (2007) and de Bruijn et al. (2006) respectively. The fossiliferous sediments, which crop out some $15 \mathrm{~km}$ north-east of Izmir, are in the lower part of the Soma Formation of early Miocene age (Text-fig. 1). Micromammals from the deposits (Tab. 1) (de Bruijn et al. 2006, Bilgin et al. 2019) indicate correlation to MN 3 of the European land mammal zonation, which is equivalent in age to Faunal Set P1 of the African faunal zonation (Pickford 1981). This correlation suggests an age of ca. 18-20 Ma for the Turkish deposits.

Remains of a few medium-sized mammals were collected at Sabuncubeli during screening for small mammals, and these include a small tragulid "Dorcatherium symirnensis" MAYDA et RösSNER, 2007, as well as the suid specimens described herein. A lophocyonid carnivoran, Izmirictis cani was defined on the basis of fossils from Sabuncubeli (Morales et al. 2019) where it is associated with several other carnivores: Cynelos, Broiliana, Euboictis aliverensis,
Semigenetta elegans, Palaeogale, Felidae indet. (Mayda 2010). In addition to the lophocyonid, Morales et al. (2019) listed Cynelos sp., Stromeriella sp., Semigenetta elegans, Palaeogale sp., an indeterminate felid, Dorcatherium sp. nov., Procervulus sp. and Protaceratherium sp. on which basis they inferred correlation to the lower part of MN 3.

\section{Material and methods}

Images of the Sabuncubeli fossils were captured with a Sony Cybershot digital camera and were prepared using Photoshop Elements15. Stereo pairs were mounted and the scales added manually. Teeth were measured using the method outlined by Van der Made (1996). Upper teeth are in capital letters, lower teeth in lower case (I, i - incisors, C, $\mathrm{c}$ - canines, $\mathrm{P}, \mathrm{p}$ - premolars, $\mathrm{M}, \mathrm{m}$ - molars).

The biochronological scale used in this paper is the European Land Mammal Zonation (Mein 1989) in which MN signifies Mammal Neogene, and Q signifies Quaternary. Nomenclature of the furrow system of suid molars is from Hünermann (1968).

\section{Institution and specimen abbreviations}

EUNHM Ege University Natural History Museum, Izmir, Turkey

PV Palaeontology, Vertebrates (for EUNHM)

\section{Systematic palaeontology}

Order Artiodactyla Owen, 1848

Superfamily Suoidea Gray, 1821

Family Suidae GraY, 1821

Subfamily Listriodontinae GervaIs, 1859

\section{Genus Prolistriodon gen. nov.}

Ty p e species. Prolistriodon smyrnensis sp. nov.

Derivatio nominis. Pro- from the Greek for 'before; primitive or early form' and Listriodon VON MEYER, 1846 (spade tooth) a well-established Miocene suid genus. 


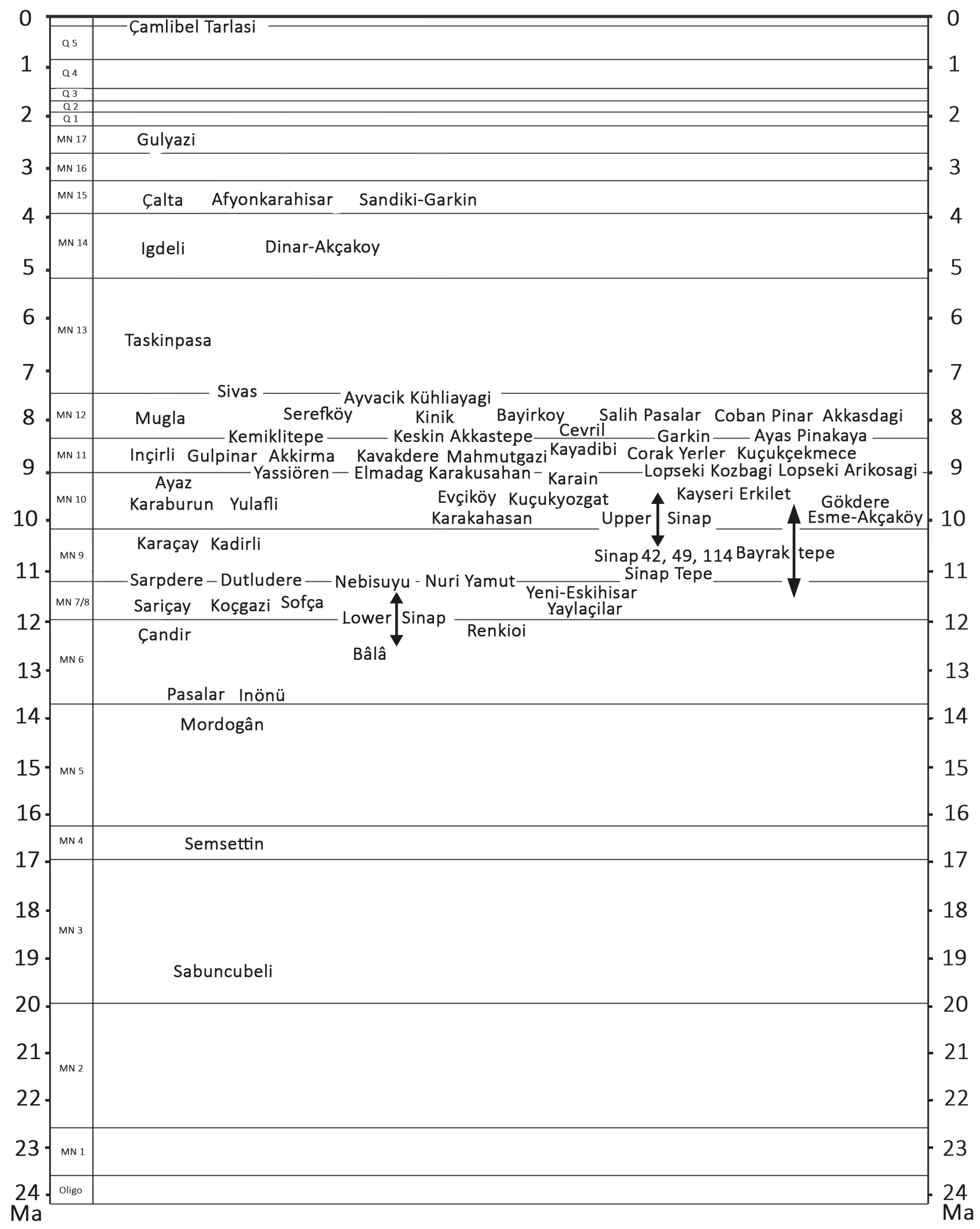

Text-fig. 2. Biochronology of Turkish localities which have yielded fossil Suidae. Correlation is to the European Land Mammal (MN) zonation with ages estimated in millions of years (Hilgen 2012).

Stehlin (1899: 286) used the word "Prolistriodon" (in quotation marks) while discussing canine morphology of Oligocene suids, but the intention was not to create a new genus but to postulate what the canine in an ancestral listriodont would look like. No description or diagnosis or indication (sensu Art. 12.2 of ICZN 1999) was accompanied with this "name" by Stehlin (1899), so even if this were supposed to be a conditionally described genus name (which 

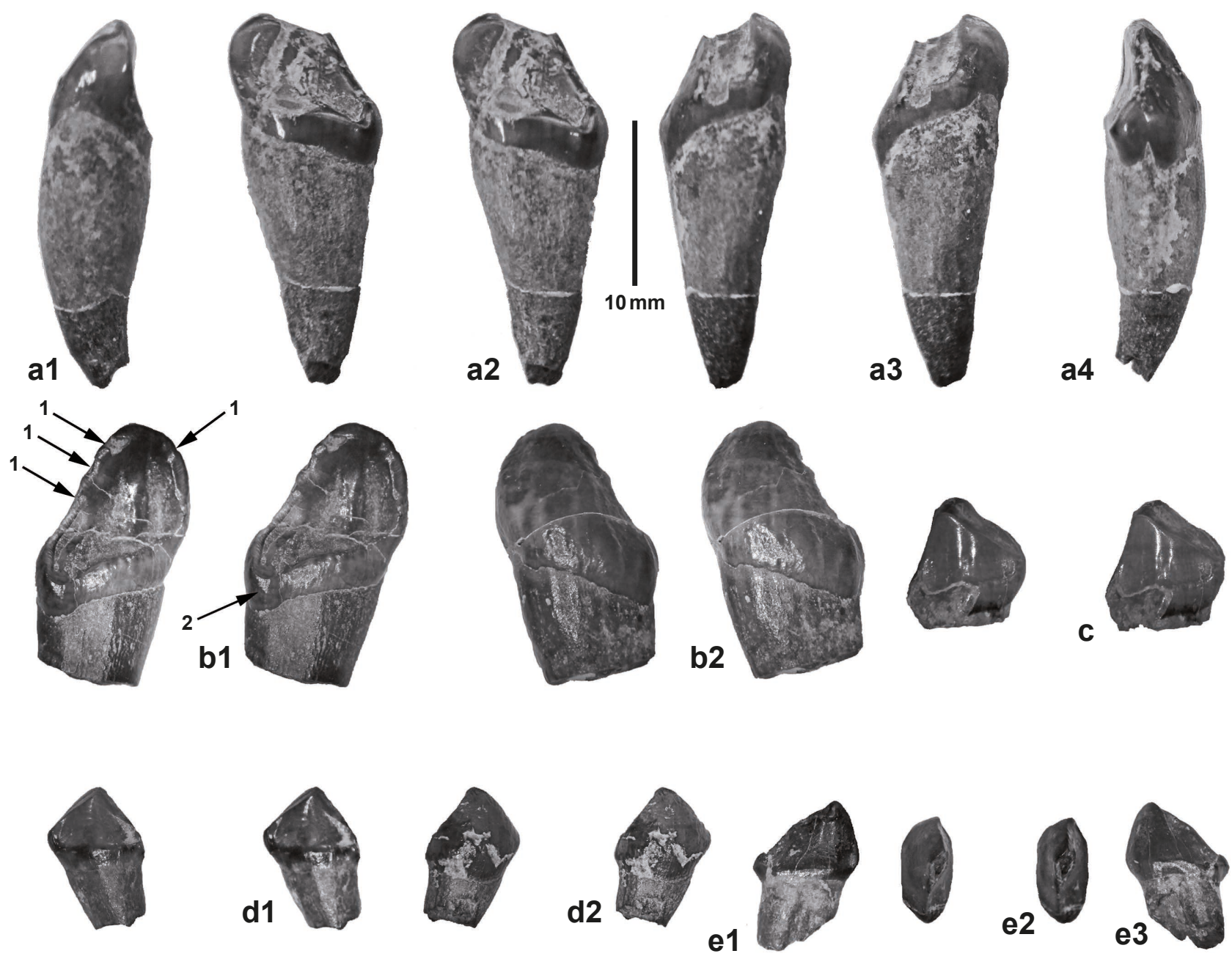

Text-fig. 3. Upper incisors and female canine of Prolistriodon smyrnensis gen. et sp. nov. from Sabuncubeli, Turkey. a: EUNHM PV 3300.b, left I1/ (a1 - mesial, a2 - stereo lingual, a3 - stereo labial, a4 - distal views); b: EUNHM PV 3300.a, right I1/ (b1 - stereo lingual, b2 - stereo labial views); c: EUNHM PV 3300.t, right I3/, stereo lingual view; d: EUNHM PV 3300.s, left I3/ (d1 - stereo lingual, d2 - stereo labial views); e: EUNHM PV 3300.r, female right canine (e1 - buccal, e2 - stereo occlusal, e3 - lingual views). Arrows show (1) shallow crenulations in the margins of the crown of I1/, (2) distal heel of I1/.

does not seem probable because it was not connected with any particular specimen), the name was a nomen nudum. This means that the name Prolistrodon is not preoccupied and can be use as a valid name.

$\mathrm{D}$ i a g n o s i s. Small suid with incipient subdivisions in the apical margin of the I1/, small distal heel in I1/, conical tapering root in I1/, I3/ low-crowned and triangular in lingual view, $\mathrm{i} / 2$ tall with scoop-shaped depression on the distal half of the lingual surface, low-crowned $i / 3, p / 2$ with robust post-cristid, well-developed lingual prehypocrista in upper molars, buccal cingulum in upper molars, tendency towards lophodonty in the molars, double-cusped centrally positioned hypoconulid in $\mathrm{m} / 3$.

Differential diagnosis. Prolistriodon differs from other listriodonts (Eurolistridon PICKFORD et MOYÀSolÀ, 1995, Bunolistriodon ArAmBourg, 1963, Listriodon VON MEyer, 1846) by its smaller dimensions and by the less spade-like upper central incisors. It differs from palaeochoerines (Palaeochoerus Pomel, 1847) by the low-crowned $\mathrm{I} 3 /$ and $\mathrm{i} / 3$ and the presence of a buccal cingulum in the upper molars. Prolistriodon differs from similar-sized hyotheriines (Aureliachoerus GinsBuRG, 1974, Hyotherium von Meyer, 1834, Sinapriculus LiU, ForTELIUS et PiCKFORD, 2002) by the absence of a metacone in the upper central incisor. It differs from tetraconodonts by possessing unreduced anterior premolars. It differs from suines by the absence of a metacone in the upper central incisors. Prolistriodon differs from small kubanochoeres (Nguruwe Pickford, 1986, Kenyasus Pickford, 1986) by possessing low-crowned i/3 and well-developed postcrista in the upper premolars and postcristid in the lower premolars, buccal cingulum and lingual prehypocrista present in the upper molars. It differs from large kubanochoeres by its considerably smaller dimensions and by the less barrel-shaped root of the upper central incisor. Prolistriodon differs from Namachoerinae PICKFORD, 1995, by its more bundont cheek dentition. It differs from Cainochoerinae PICKFord, 1993 (Cainochoerus PICKFORD, 1988, Albanohyus GinsBurG, 1974) by its greater dimensions, the low-crowned $\mathrm{i} / 3$ and the presence of enamel on all sides of the incisor crowns. 


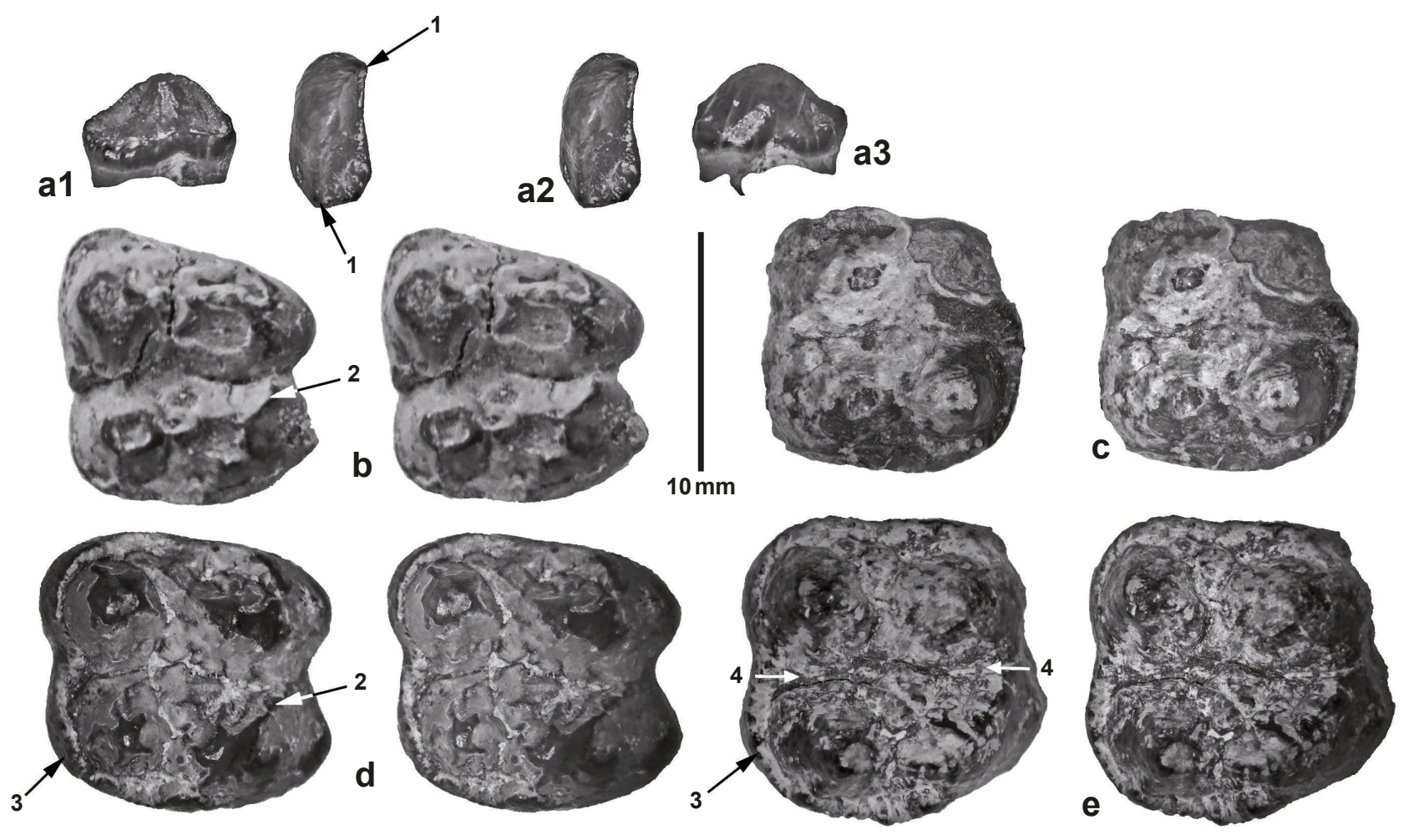

Text-fig. 4. Upper cheek teeth of Prolistriodon smyrnensis gen. et sp. nov. from Sabuncubeli. a: EUNHM PV 3300.q, right P2/ (a1 lingual, a2 - stereo occlusal, a3 - buccal views); b: EUNHM PV 3300.h, right D4/, stereo occlusal view; c: EUNHM PV 3300.i, left M1/, stereo occlusal view; d: EUNHM PV 3300.k, right M2/, stereo occlusal view; e: EUNHM PV 3300.j, right M2/, stereo occlusal view. Arrow 1 shows the strongly developed pre- and postcrista of the P2/, arrow 2 shows the lingual prehypocrista in the upper molars, arrow 3 shows the buccal cingulum in the upper molars, arrow 4 shows the rectilinear median transverse valley.

\section{Prolistriodon smyrnensis sp. nov.}

Text-figs 3-6

H o l o t y p e. EUNHM PV 3300.a, right I1/.

Derivatio nominis. The species name is for Smyrna, the ancient name for Izmir, with the suffix "ensis" with the sense of "from".

Type locality and age. Sabuncubeli, Turkey, early Miocene, MN 3 basal part.

Diagnosis. As for the genus (length $\mathrm{m} / 1-\mathrm{m} / 3$ ca. $53.5 \mathrm{~mm})$.

Other material from Sabuncubeli. EUNHM PV 3300.b - 3300.w, diverse isolated upper and lower teeth (Tab. 2).

Description. The upper central incisors from Sabuncubeli are slightly spatulate with a concave lingual surface interrupted by a low central ridge, bordered cervically by a well-developed, lightly beaded cingulum. The labial surface is convex, and there is a slight distal extension of the crown, but no development of a separate cusp (metacone in the terminology of Van der Made 1996). The root is twice as tall as the crown, is compressed conical and tapers apically to a point. In the lightly worn holotype specimen (PV3300.a; Text-fig. 3b) the apical margin shows slight indentations, one to the mesial side of the lingual ridge, the others along the distal margin of the crown.

In labial and lingual views, the upper third incisors from Sabuncubeli have low, triangular crowns. There is a strong lingual cingulum, a well-developed lingual ridge on a generally concave lingual surface, and a slightly convex labial surface (Text-fig. 3d).

The upper female canine is two-rooted, with the roots fused together almost to their apices (Text-fig. 3e). The crown is labio-lingually compressed and in labial view is triangular, with a short anterior crista and an elongated posterior crista with a distal heel.

In occlusal view, a P2/ from Sabuncubeli (PV 3300.q) is almost quadrangular with rounded corners, being slightly narrower mesially than distally (Text-fig. 4a). The main cusp is almost centrally positioned with an oblique precrista terminating in the mesio-lingual corner of the crown, and a postcrista leading distally to the bucco-distal corner of the tooth. There is a moderately-sized lingual concavity bordered by a lingual cingulum.

The D4/ (PV 3300.h) has a trapezoidal occlusal outline, the buccal border being significantly longer than the lingual one (Text-fig. 4b). It has thinner enamel than the permanent molars. There are four main cusps with relatively shallow Furchen (sensu Hünermann 1968) and small anterior, median and posterior accessory cusplets. Mesial and distal cingula are present and the buccal cingulum is narrow and discontinuous. The hypocone has a prominent precrista leading towards the lingual end of the median transverse valley but not blocking it.

The upper molars from Sabuncubeli are typical of bundont suids, with four main cusps (protocone, paracone, hypocone, metacone) arranged in two lophs, and three accessory cusplets (anterior, median, posterior) disposed along the midline of 

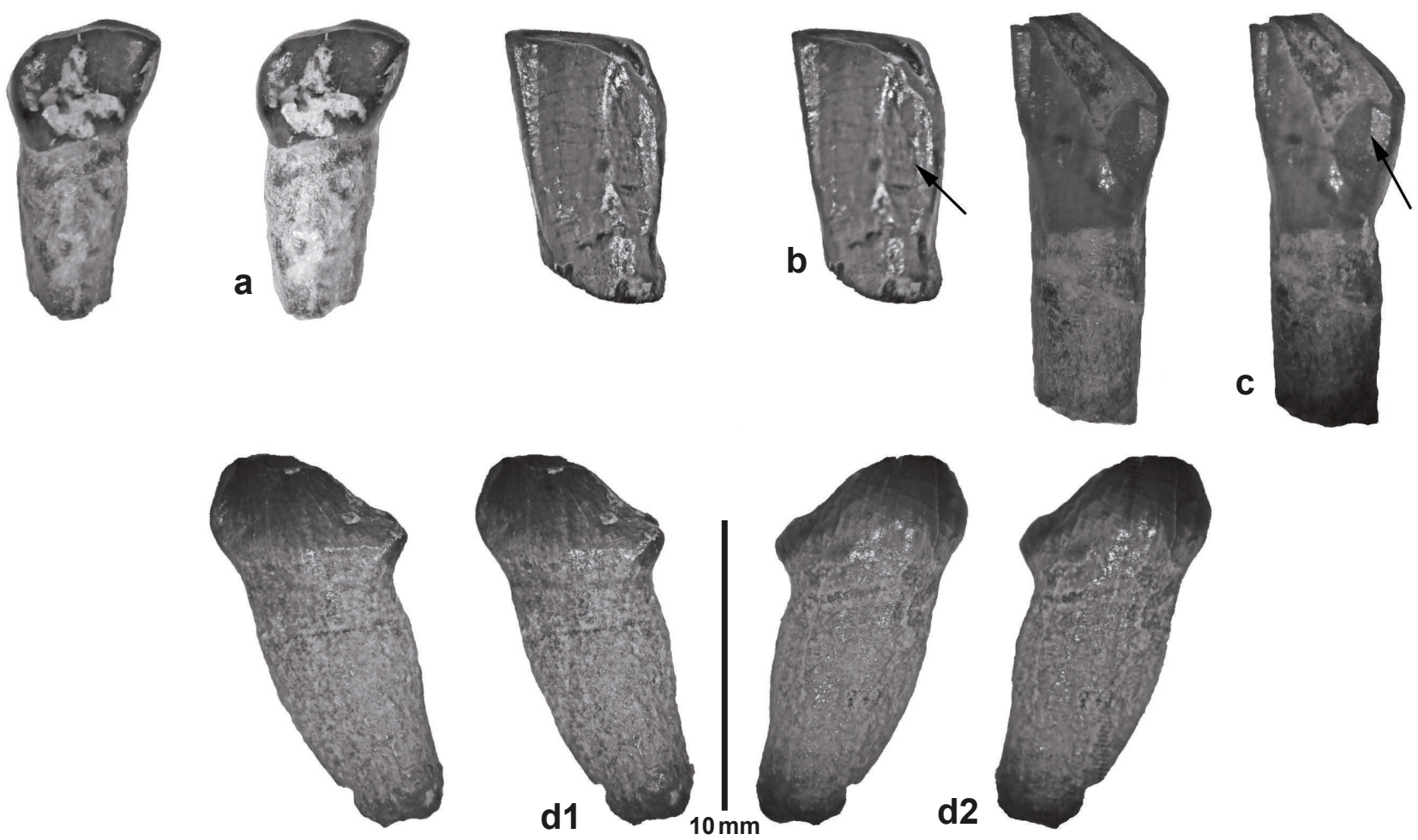

Text-fig. 5. Lower incisors and female canine of Prolistriodon smyrnensis gen. et sp. nov. from Sabuncubeli, Turkey. a: EUNHM PV 3300.n, left i/3, stereo lingual view; b: EUNHM PV 3300.l, right i/2, stereo lingual view; c: EUNHM PV 3300.m, right i/2, stereo lingual view; d: EUNHMPV 3300.v, right female canine (d1 - stereo lingual, d2 - stereo labial views). The arrows show the distal scoop-like depression in the tall-crowned $\mathrm{i} / 2$, note the low-crowned $\mathrm{i} / 3$.

the crown (Text-fig. 4c-e). The Furchen are shallow. The hypocone has a well-developed lingual precrista that leads towards the lingual end of the median transverse valley. There are strong mesial, buccal and distal cingula. The median transverse valley is partly blocked by the median accessory cusplet but this cusplet is mostly positioned between the mesial aspects of the metacone and hypocone.

The lower second incisors from Sabuncubeli have quite tall crowns, with a slightly scoop-shaped depression on the distal side of the central lingual ridge (Text-fig. 5b, c). There are clear mesial and distal ridges bordering the lingual side of the crown.

The third lower incisor, in contrast to the $\mathrm{i} / 2$, is a lowcrowned tooth, significantly lower than the $\mathrm{i} / 2$ (Text-fig. 5a). It has a lingual cingulum and a lingual ridge that runs towards the distal corner of the crown, thereby separating the lingual surface of the tooth into two concave parts. On the lingual side there are low mesial and distal crests.

The lower female canine is a single-rooted tooth with a strongly labio-lingually compressed crown (Text-fig. $5 \mathrm{~d})$. The precristid is short and steep, the postcristid long and more gently sloping distally, ending in a low heel-like cusplet.

The $\mathrm{p} / 2$ of the Sabuncubeli suid is two-rooted, with a bucco-lingually compressed crown (Text-fig. 6a). The protoconid is tall and centrally positioned with steep preand postcristids, the latter one separating buccal and lingual concavities in the crown profile. It descends towards the disto-buccal corner of the crown where it joins a disto- lingual swelling in the crown. There are weak anterior and posterior cingulids.

The $\mathrm{p} / 3$ is larger than the $\mathrm{p} / 2$, and has a distinct swelling in the posterior part of the postcristid which almost forms a separate cusplet in the mid-line of the tooth (Text-fig. 6b). The mesial and distal cingulids are well developed and the disto-lingual part of the crown extends distally further than the disto-buccal part.

Only the third lophid of the $\mathrm{d} / 4$ is preserved in the Sabuncubeli sample (Text-fig. 6c). The main cuspids are scored by shallow Furchen and the median and posterior accessory cusplets are positioned in the centre-line of the tooth.

The first and second lower molars from Sabuncubeli are tetracuspidate with anterior, median and posterior accessory cusplets (Text-fig. 6d-f). The Furchen are shallow. The precristids of the protoconid and metaconid extend towards the anterior accessory cusplet. The distal surfaces of the protoconid and metaconid have two cristids descending from their apices, the outer ones descending almost vertically, the inner ones approaching each other in the mid-line of the crown, the ensemble forming an ' $\mathrm{m}$ '-shaped structure somewhat resembling the ' $\mathrm{M}$ '-structure in tragulid teeth. The hypoconid has two cristids, one joining the median accessory cusplet, the other reaching steeply towards the posterior accessory cusplet. The entoconid is conical with four cristids, the outer ones stronger than the inner ones. The mesial and distal cingulids are weak and there is a cingular structure traversing the buccal end of the median transverse valley. 


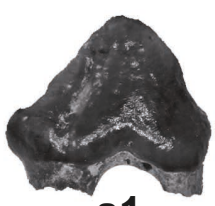

a1

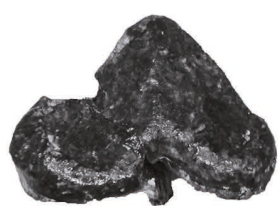

b1
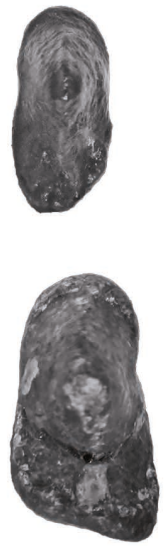

b2
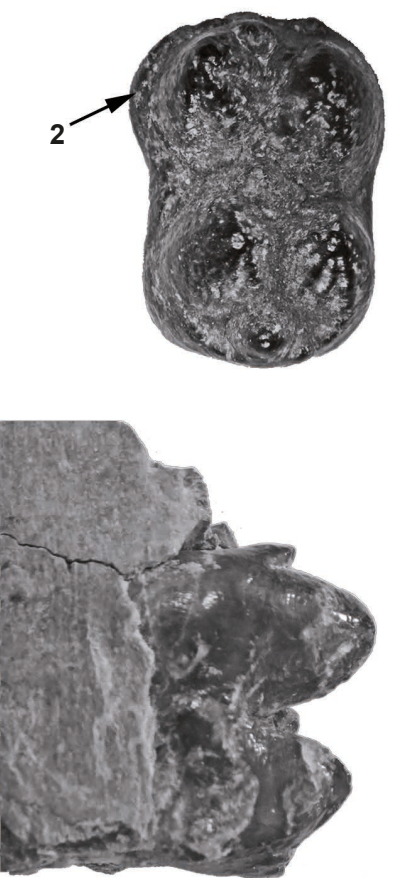

f1

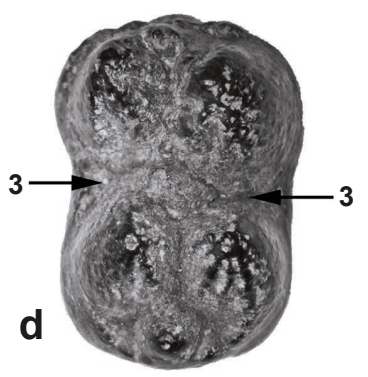

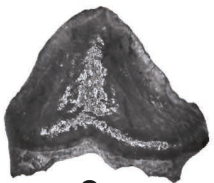

a3

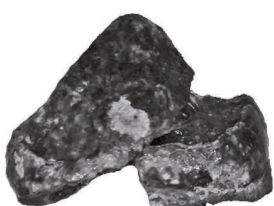

b3
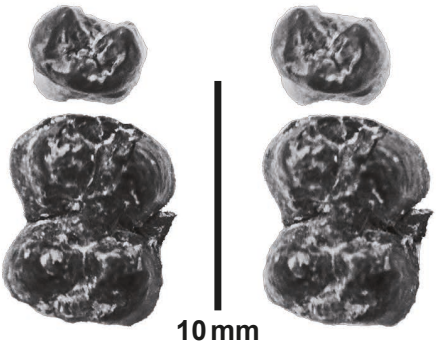

C
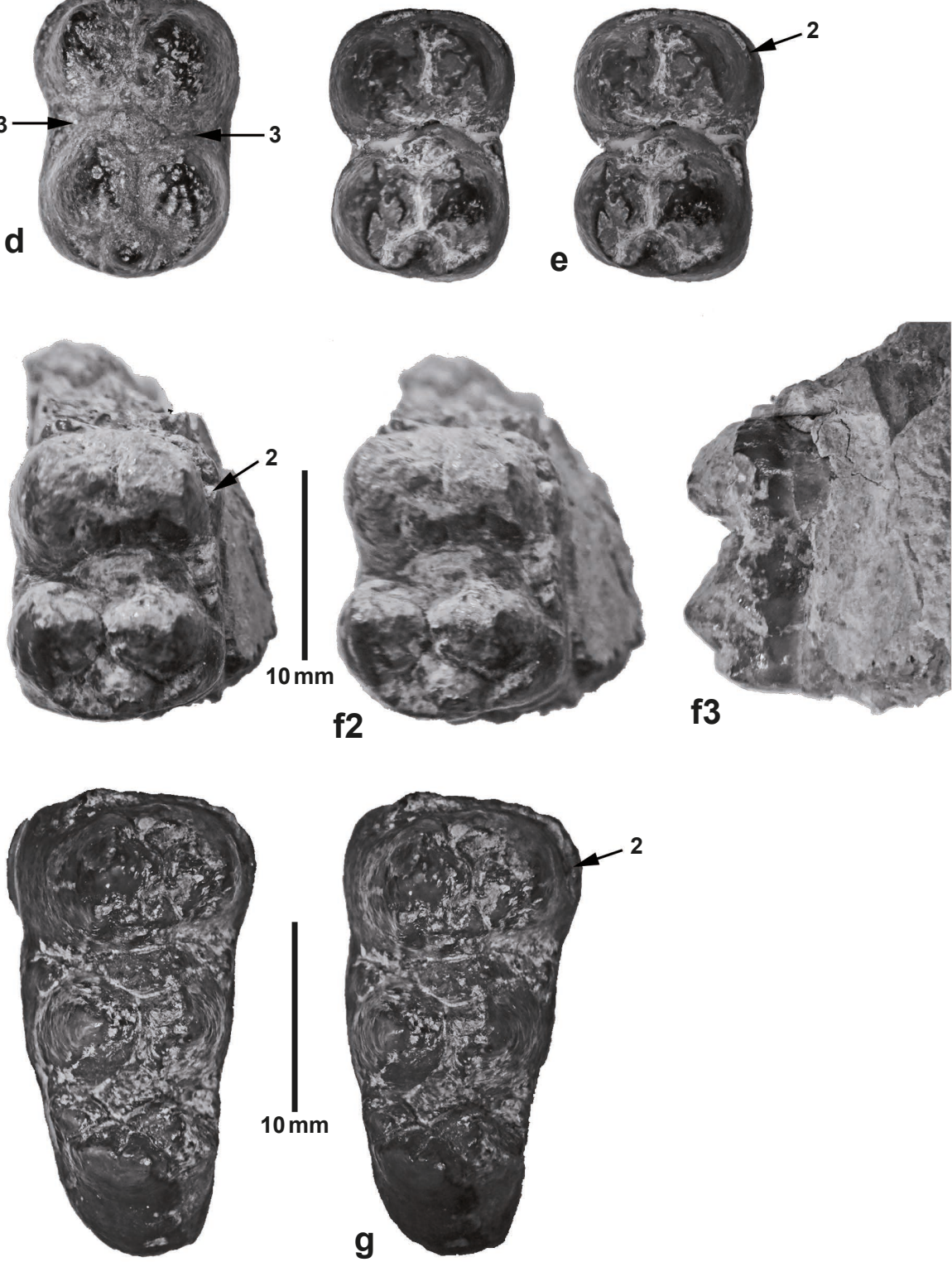

Text-fig. 6. Lower cheek teeth of Prolistriodon smyrnensis gen. et sp. nov. from the early Miocene of Sabuncubeli, Turkey. a: EUNHM PV 3300.o, right p/2 (a1 - buccal, a2 - stereo occlusal, a3 - lingual views); b: EUNHM PV 3300.p, right p/3 (b1 - lingual, b2 - stereo occlusal, b3 - buccal views); c: EUNHM PV 3300.c, left d/4-m/1, stereo occlusal view; d: EUNHM PV 3300.e, right m/2, stereo occlusal view; e: EUNHM PV 3300.d, right m/1, stereo occlusal view; f: EUNHM PV 3300.f, right mandible fragment with m/2 (f1 - lingual, f2 - stereo occlusal, f3 - buccal views); g: EUNHM PV 3300.g, right m/3, stereo occlusal view. Arrow 1 shows the strongly developed postcristid of the $\mathrm{p} / 2$, arrow 2 shows the buccal cingulum in the lower molars, arrow 3 shows the median transverse valley blocked by a large median accessory cusplet, note the bifid hypoconulid in the $\mathbf{m} / 3$. 
Table 1. Microfauna from Sabuncubeli, Turkey.

\begin{tabular}{|c|c|}
\hline de Bruijn et al. 2006 & Bilgin et al. 2019 \\
\hline $\begin{array}{l}\text { Galerix uenayae } \\
\text { Schizogalerix evae } \\
\text { Desmanodon cf. burkarti } \\
\text { Soricid gen. et sp. indet. } \\
\text { Ochotonidae gen. et sp. indet. } \\
\text { Steneofiber eseri } \\
\text { Debruijnia arpati } \\
\text { Mirabella anatolicalcrenulata exemplum intercentrale } \\
\text { Cricetodon aff. kasapligili } \\
\text { Eumyarion intercentralis } \\
\text { Eumyarion orhani } \\
\text { Eumyarion montanus } \\
\text { Vallaris zappai } \\
\text { Democricetodon doukasi } \\
\text { Glis galitopouli } \\
\text { Glirudinus cf. engesseri } \\
\text { Palaeosciurus fissurae }\end{array}$ & $\begin{array}{l}\text { Galerix uenayae } \\
\text { Schizogalerix evae } \\
\text { Theratiskos sp. } \\
\text { Desmanodon sp. } \\
\text { Desmanodon cf. burkarti } \\
\text { Turkodimylus sp. } \\
\text { Oligosorex aff. reumeri } \\
\text { Vespertilionidae gen. et sp. indet. } \\
\text { Eumyarion cf. montanus } \\
\text { Eumyarion orhani } \\
\text { Eumyarion intercentralis } \\
\text { Mirabella anatolicalcrenulata complex } \\
\text { Cricetodon kasapligili } \\
\text { Democricetodon doukasi } \\
\text { Vallaris zappai } \\
\text { Glis galitopouli } \\
\text { Glirudinus engesseri } \\
\text { Glirulus ekremi } \\
\text { Palaeosciurus fissurae }\end{array}$ \\
\hline
\end{tabular}

Table 2. Measurements (in mm) of the teeth of Prolistriodon smynensis gen. et sp. nov. from Sabuncubeli, Turkey (EUNHM PV 3300.). BLB - bucco-lingual breadth, $f$ - female, It - left, MDL - mesio-distal length, rt - right.

\begin{tabular}{|l|c|c|c|}
\hline \multicolumn{1}{|c|}{ Catalogue no. } & Tooth & MDL & BLB \\
\hline EUNHM PV 3300.v & $\mathrm{c} / 1 \mathrm{f} \mathrm{rt}$ & 6.1 & 3.1 \\
\hline EUNHM PV 3300.r & $\mathrm{C} 1 / \mathrm{f} \mathrm{rt}$ & 6.5 & 3.2 \\
\hline EUNHM PV 3300.w & $\mathrm{d} / 3 \mathrm{rt}$ & 5.6 & 3.1 \\
\hline EUNHM PV 3300.c & $\mathrm{d} / 4 \mathrm{lt}$ & - & 5.1 \\
\hline EUNHM PV 3300.h & $\mathrm{D} 4 / \mathrm{rt}$ & 11.0 & 10.2 \\
\hline EUNHM PV 3300.1 & $\mathrm{i} / 2 \mathrm{rt}$ & 5.4 & 4.9 \\
\hline EUNHM PV 3300.m & $\mathrm{i} / 2 \mathrm{rt}$ & 5.6 & 4.9 \\
\hline EUNHM PV 3300.n & $\mathrm{i} / 3 \mathrm{lt}$ & 5.3 & 3.7 \\
\hline EUNHM PV 3300.b & $\mathrm{I} 1 / \mathrm{lt}$ & 10.9 & 6.2 \\
\hline EUNHM PV 3300.a & $\mathrm{I} 1 / \mathrm{rt}$ & 11.0 & 6.2 \\
\hline EUNHM PV 3300.s & $\mathrm{I} 3 / \mathrm{lt}$ & 7.0 & 4.2 \\
\hline EUNHM PV 3300.t & $\mathrm{I} 3 / \mathrm{rt}$ & 6.8 & 4.3 \\
\hline EUNHM PV 3300.c & $\mathrm{m} / 1 \mathrm{lt}$ & 10.0 & 8.0 \\
\hline EUNHM PV 3300.d & $\mathrm{m} / 1 \mathrm{rt}$ & 14.5 & 10.1 \\
\hline EUNHM PV 3300.e & $\mathrm{m} / 2 \mathrm{lt}$ & 15.0 & 11.2 \\
\hline EUNHM PV 3300.f & $\mathrm{m} / 2 \mathrm{rt}$ & 15.5 & 11.6 \\
\hline EUNHM PV 3300.g & $\mathrm{m} / 3 \mathrm{rt}$ & 23.4 & 12.3 \\
\hline EUNHM PV 3300.i & $\mathrm{M} 1 / \mathrm{lt}$ & 11.5 & 11.5 \\
\hline EUNHM PV 3300.j & $\mathrm{M} 2 / \mathrm{rt}$ & 12.3 & 12.4 \\
\hline EUNHM PV 3300.k & $\mathrm{M} 2 / \mathrm{rt}$ & 11.5 & 12.4 \\
\hline EUNHM PV 3300.u & $\mathrm{p} / 2$ & - & 4.0 \\
\hline EUNHM PV 3300.o & $\mathrm{p} / 2 \mathrm{rt}$ & 8.3 & 4.0 \\
\hline EUNHM PV 3300.p & $\mathrm{p} / 3 \mathrm{lt}$ & 10.8 & 6.0 \\
\hline EUNHM PV 3300.q & $\mathrm{P} 2 / \mathrm{rt}$ & 7.3 & 3.8 \\
\hline
\end{tabular}

The $\mathrm{m} / 3$ is like the $\mathrm{m} / 2$ but has a third lophid behind the posterior accessory cusplet (Text-fig. 6g). This talonid (hypoconulid) is comprised of two parts, a large distal cusplet with a strong mesially directed, beaded cristid on the lingual side, and a slightly smaller buccal cuspid which touches the posterior accessory cusplet. The mesial cingulum is quite strong, and there are cingular remnants in the buccal and lingual ends of the median and posterior transversevalleys.

\section{Discussion}

\section{Systematic affinities}

The small suid teeth from Sabuncubeli are typical of bunodont suids in general, but they show several hints of development of morphological structures that recall features found in much larger species of Listriodontinae (Text-fig. 7). The unworn I1/ has nascent notches in the apical part of the crown which could correspond to the clear sulci that occur in the upper central incisors of Listriodon but the crowns of the Subuncubeli incisors are not expanded mesio-distally as much as those of listriodonts, but in this respect they are somewhat like those of Nguruwe and Palaeochoerus (Pickford 2016b). The I3/ is triangular in lingual view, with a clear lingual cingulum, as in listriodonts. The $\mathrm{i} / 2$ is tall with a distal scoop-like structure on its lingual surface and the $i / 3$ is low-crowned, a combination also typical of listriodonts, and somewhat different from those of other suids in which the $\mathrm{i} / 3$ tends to be almost as tall as the $\mathrm{i} / 2$ (with the exception of advanced kubanochoeres).

Overall, the molars from Sabuncubeli are morphologically primitive within a suid context, resembling those of Palaeochoerus, small species of Hyotherium and, apart from their diminutive dimensions, even those of bunodont listriodonts. In particular, the upper molars from Sabuncubeli have a well-developed lingual precrista on the hypocone, similar to the structure found in some bunodont listriodonts such as Listriodon retamaensis PICKFORD et Morales, 2003 (Pickford and Morales 2016), and Bunolistriodon lockharti 

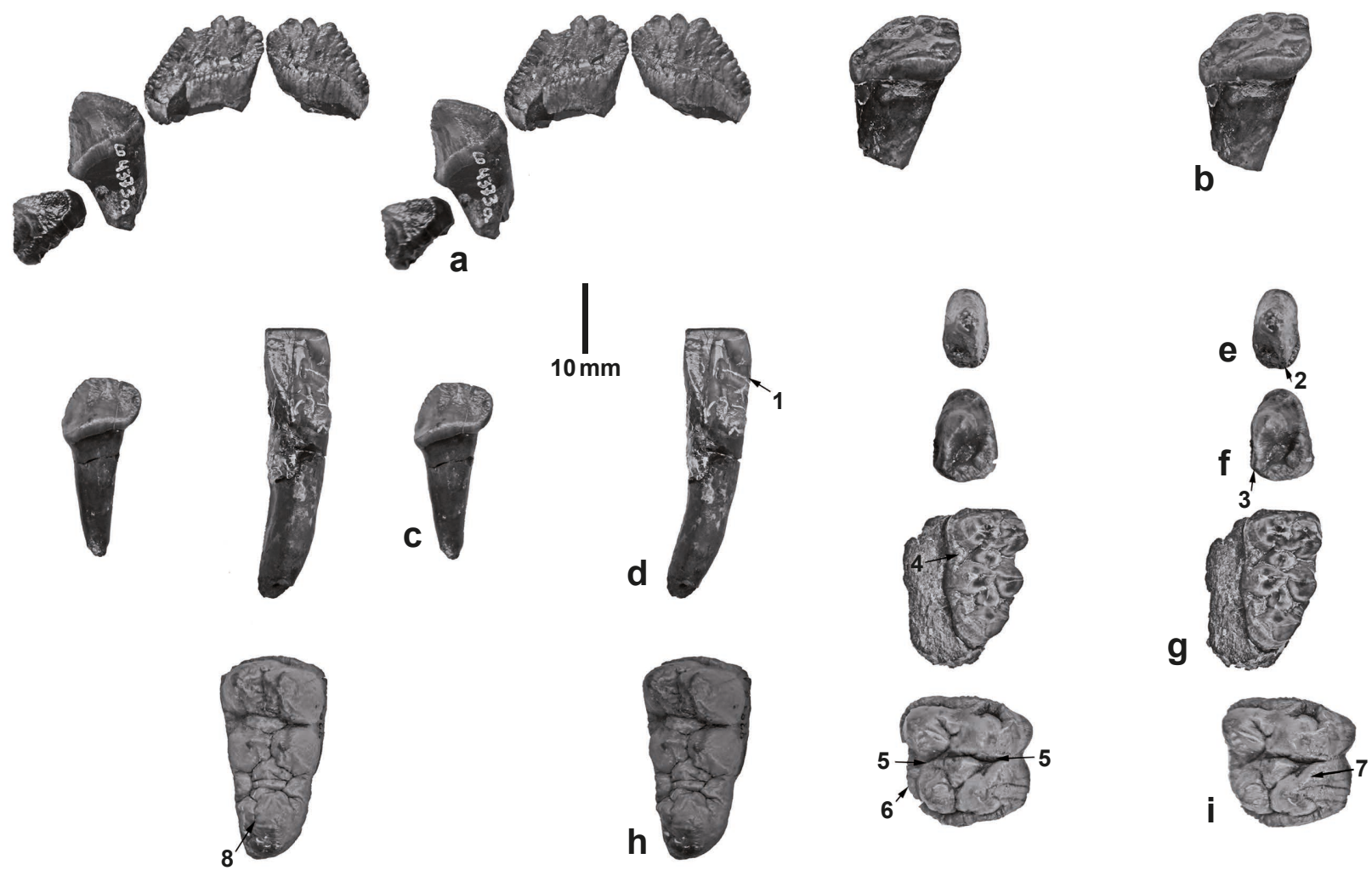

Text-fig. 7. Stereo views of bunodont listriodont suid teeth from Córcoles, Spain (MN 4) for comparison with the Sabuncubeli fossils. a: lingual view of upper incisors (note the apical crenulations in I1/ and the triangular I2/ and I3/); b: lingual view of right I1/ (note the apical crenulations and the conical tapering root); c: lingual view of left i/3 (note the low, triangular crown); d: right $\mathrm{i} / 2$ (note the tall crown and distal scoop-shaped depression - arrow 1); e: occlusal view of right $\mathrm{p} / 2$ (note the well-developed postcristid - arrow 2); f: occlusal view of right P2/ (note the strongly developed postcrista (arrow 3); g: occlusal view of left $\mathrm{m} / 3$ (note the buccal cingulum - arrow 4); h: occlusal view of left $\mathrm{m} / 3$ (arrow 8 shows the bifid hypoconulid); i: occlusal view of right M2/ (arrow 5 shows the rectilinear median transverse valley, arrow 6 shows the buccal cingulum and arrow 7 shows the welldeveloped lingual prehypocrista in the upper molar).

Table 3. Summary of derived features shared between Prolistriodon smyrnensis gen. et sp. nov. and Listriodon retamaensis.

\begin{tabular}{|l|l|l|}
\hline \multicolumn{1}{|c|}{ Tooth } & \multicolumn{1}{|c|}{ Prolistriodon smyrnensis } & \multicolumn{1}{|c|}{ Listriodon retamaensis } \\
\hline I1/ & $\begin{array}{l}\text { Shallow apical crenulations } \\
\text { Distal heel small } \\
\text { Rapidly tapering root }\end{array}$ & $\begin{array}{l}\text { Deep apical crenulations } \\
\text { Distal heel large } \\
\text { Rapidly tapering root }\end{array}$ \\
\hline I3/ & $\begin{array}{l}\text { Reduced height } \\
\text { Triangular lingual outline }\end{array}$ & $\begin{array}{l}\text { Reduced height } \\
\text { Triangular lingual outline }\end{array}$ \\
\hline Upper molars & $\begin{array}{l}\text { Prominent lingual prehypocrista } \\
\text { Well-developed buccal cingulum } \\
\text { Lophodont tendency }\end{array}$ & $\begin{array}{l}\text { Prominent lingual prehypocrista } \\
\text { Well-developed buccal cingulum } \\
\text { Lophodont tendency }\end{array}$ \\
\hline $\mathrm{i} / 2$ & $\begin{array}{l}\text { Distal scoop present } \\
\text { Strong lingual ridge }\end{array}$ & $\begin{array}{l}\text { Distal scoop large } \\
\text { Strong lingual ridge }\end{array}$ \\
\hline i/3 & Reduced height & Reduced height \\
\hline p/2 & Prominent post-cristid & Prominent post-cristid \\
\hline Lower molars & $\begin{array}{l}\text { Tendency to lophodonty } \\
\text { Buccal cingulids present }\end{array}$ & $\begin{array}{l}\text { Tendency to lophodonty } \\
\text { Buccal cingulids usually present (variable) }\end{array}$ \\
\hline $\mathrm{m} / 3$ & $\begin{array}{l}\text { Double-cusped hypoconulid } \\
\text { Hypoconulid centrally positioned }\end{array}$ & $\begin{array}{l}\text { Double-cusped hypoconulid } \\
\text { Hypoconulid centrally positioned }\end{array}$ \\
\hline
\end{tabular}


Pomel, 1848. They also have a buccal cingulum like the same two listriodont species (Tab. 3). Another similarity to Listriodon retamaensis is the fact that the hypoconulid of the $\mathrm{m} / 3$ is usually closely associated with a secondary talonid cusplet, unlike most Palaeochoerinae and Kubanochoerinae which usually have a single talonid cusp in the $\mathrm{m} / 3$ (Pickford and Tsujikawa 2019).
Even though the sample from Sabuncubeli is limited, it covers many of the permanent tooth positions, permitting the fossil assemblage to be attributed to a new genus and species, Prolistriodon smyrnensis, partly on account of its dimensions but primarily on the suite of dental resemblances in morphology that it shares with corresponding teeth of Listriodon retamaensis and other bunodont listriodonts.

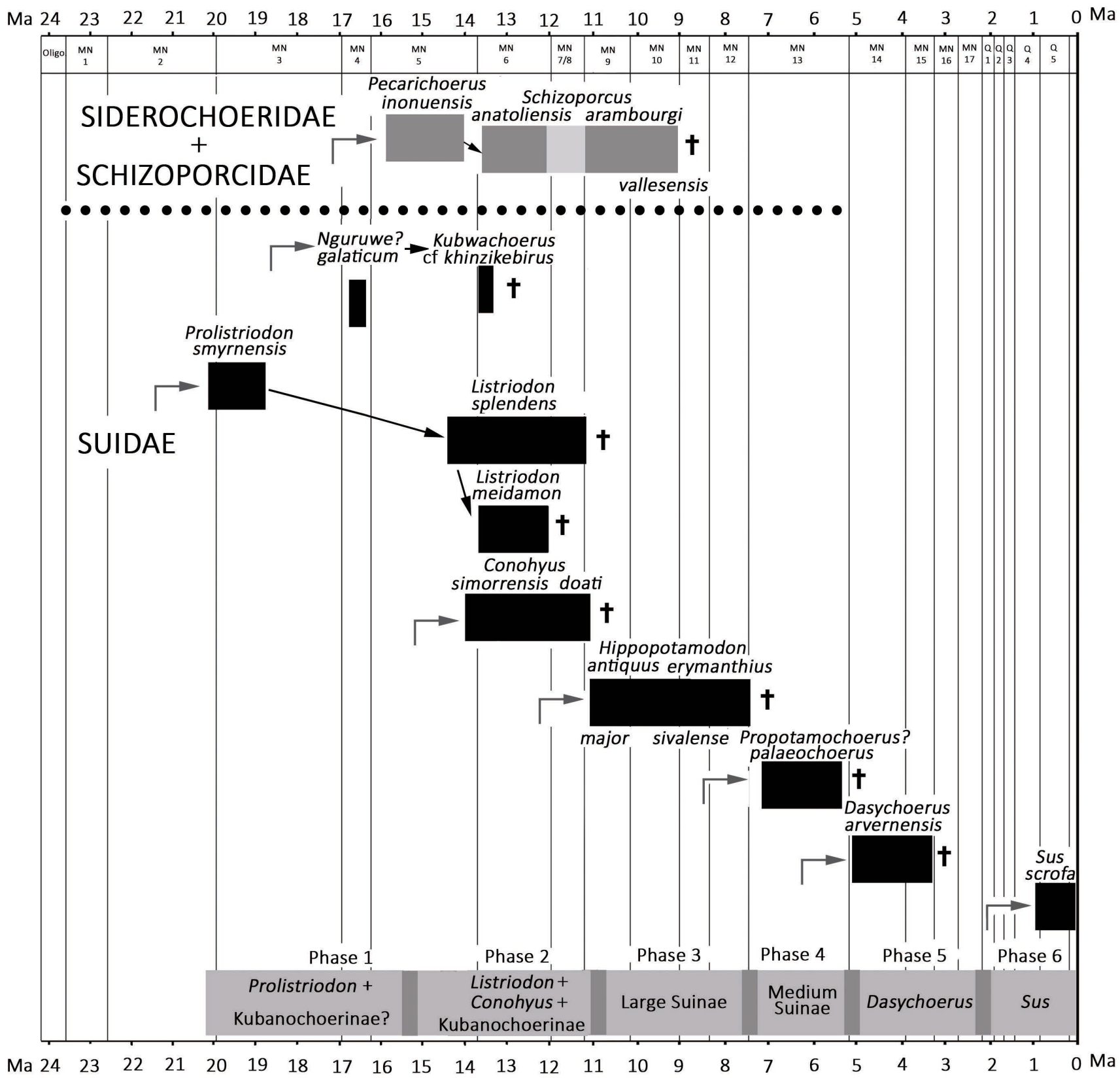

Text-fig. 8. Neogene and Quaternary Suoidea of Turkey. Among the Suidae, six phases of populations can be discerned, beginning with small primitive listriodonts and possibly small kubanochoeres in Phase 1 (MN 3-4), followed by Phase 2 (MN 5-8) which was dominated by medium-sized to large listriodonts and tetraconodonts accompanied by a rare large kubanochoere, following which an abrupt change close to the Hipparion datum (ca. 11.5 Ma) occurred, during which listriodonts and tetraconodonts went extinct, followed by the influx of large suines which dominated Phase 3 (MN 9-12) followed in its turn by the disappearance of large suines, giving way to medium-sized suines in Phase 4 (MN 13). This was followed by Phase 5 (Pliocene, MN 14-15) when tropically adapted Dasychoerus dispersed to Turkey, ending with the disappearance of Dasychoerus before the Pleistocene and its replacement by boreally adapted Sus (Phase 6; Quaternary, MN 17 - Q 5). Black arrows - possible phylogenetic links, bent grey arrows - lineages immigrant to Turkey, + symbol - extinction within Turkey. Data used to compile this figure are from Malik and Nafiz 1933, Thenius 1949, Senyürek 1952, Ozansoy 1957, 1965, Hünermann 1975, Pickford and Ertürk 1979, Fortelius and Bernor 1990, Fortelius et al. 1996, Van der Made and Tuna 1999, Van der Made 2003, Geraads et al. 2005, Liu et al. 2005, Yakut 2012, Bartosiewicz et al. 2013, Van der Made et al. 2013, Orliac et al. 2015, Pickford 2016a, Kostopoulos et al. 2016. 
Despite the relative paucity of remains from Sabuncubeli, appurtenance to other small early and middle Miocene suids such as Palaeochoerus Pomel, 1847, Hyotherium von Meyer, 1834, or Aureliachoerus Ginsburg, 1974, can be excluded on account of the major differences that the incisors that these genera display. Attribution to Nguruwe PicKFORD, 1986, or Kenyasus PiCKFORD, 1986, can also be excluded on account of the fact that in both these African genera, the $i / 3$ is almost as tall as the $\mathrm{i} / 2$ (Pickford and Tsujikawa 2019) not low like the specimen from Sabuncubeli.

It is considered likely that the suid species from Sabuncubeli could have given rise to classic listriodonts (Eurolistriodon, Bunolistriodon, Listriodon) mainly by an increase in dimensions. The derived features of the dentition indicate that it was already part of the listriodont clade. Being from the basal part of MN 3, the Sabuncubeli suid specimens are appreciably older (ca. 2-3 million years) than other listriodont remains from Eurasia $(\mathrm{MN} \mathrm{4a})$ and are thus of a suitable age to be ancestral to classic listriodonts (Text-fig. 8).

Some small suid remains from Şemsettin (Kumartaş Formation, Çankiri-Çorum Basin) were described by Orliac et al. (2015) who interpreted them to belong to a small kubanochoere (Nguruwe? galticum). One tooth from the site was attributed to an indeterminate hyothere. This sample is rather too restricted for it to yield a confident assessment of its affinities, not only in relation to the specimens from Sabuncubeli, but also to the later suids from Turkey and other parts of the Old World (Text-fig. 8).

\section{Palaeoecology}

In general, extant mammals with lophodont cheek teeth include important quantities of leaves in their diets (for example folivorous cercopithecid monkeys, tapirs, kangaroos) (Hunter and Fortelius 1994, Fortelius et al. 1996). The presence of strongly developed precrista and postcrista in the upper premolars (postcristids in lower premolars) of Prolistriodon smyrnernsis (Text-figs 4, 6) suggests that it was including some leaves in its diet, but that it was still relatively omnivorous. The presence of a clear lingual prehypocrista and an almost straight median transverse valley in the upper molars indicates the same adaptation. Bunodont listriodonts possess similar development of the same cristae and cristids (Text-fig. 7) which also suggest that they were omnivorous but combined with a significant element of folivory, perhaps on a seasonal basis. Fully lophodont listriodonts such as Listriodon splendens, in contrast, were likely to have been dedicated folivores, deriving the bulk of their energy and dietary requirements from leaves on a year-round basis. This adaptation not only implies a constant supply of leaves all the year, but also implies digestive adaptations necessary for detoxifying toxins that occur in many fully formed mature leaves.

On this basis, it is inferred that Prolistriodon smyrnensis was likely to have been an omnivore with folivorous tendencies, perhaps consuming leaves on a seasonal basis when sufficient supplies of tender, young leaves (with a low toxin load) were available.

\section{Conclusion}

A sample of small suid teeth from Sabuncubeli, Turkey (MN 3) is attributed to a new genus and species of listriodont suids, Prolistriodon smyrnensis, on account of the diminutive dimensions and bunodont morphology of the teeth, but showing a suite of derived dental features found in Listriodon, Bunolistriodon and Eurolistriodon. The incisors are interesting in that they show signs of nascent affinities to Listriodontinae including slight sulci in the apical margin of the upper central incisors, triangular upper lateral incisors, tall-crowned lower second incisors with a scoop-like morphology on the distal half of the lingual surface, and low-crowned $\mathrm{i} / 3$. The molars also recall, in miniature, those of bunodont listriodonts such as Listriodon retamaensis: the upper molars have a clear lingual prehypocrista, a rectlinear median transverse valley and a well-developed buccal cingulum, and the lower third molar has a centrally positioned, double-cusped hypoconulid. The weight of evidence thus indicates that Prolistriodon smyrnensis was already engaged on the line towards classic Listriodontinae, and should thus be included in this subfamily. As such it is the oldest known and most primitive member of the subfamily described.

The Sabuncubeli suid fossils thus help to resolve a longstanding enigma about Listriodontinae - to wit, their supposedly sudden and roughly simultaneous appearance in Europe, Asia and Africa towards the end of the early Miocene (MN 4 in Europe and Asia, Faunal Set III in Africa) from a hitherto unknown ancestor. The plesiomorphic features of the Sabuncubeli specimens indicate that Listriodontinae were probably derived from the Palaeochoerinae (sensu Pickford 2018 b) sometime towards the end of MN 2 or the beginning of $\mathrm{MN} 3$, and that they were derived from this subfamily independently from the Kubanochoerinae, which split from the Palaeochoerinae some time earlier (Faunal Set I in Africa).

\section{Acknowledgements}

S.M. and T.K. were funded by EGE University Research Grants 2004/BIL/020, 2005/TTM/001, 2016/TTM/001 and 2016/TTM/002, and 2015/Fen/17 and the TUBITAK Research Grant YDABAG 102Y045. M.P. thanks the EUNHM for providing access to the fossils described in this paper.

\section{References}

Arambourg, C. (1963): Le genre Bunolistriodon Arambourg 1933. - Bulletin de la Société géologique de France, 5(7): 903-911. https://doi.org/10.2113/gssgfbull.S7-V.6.903

Cope, E. D. (1888): The Artiodactyla. - American Naturalist, 22: 1079-1095. https://doi.org/10.1086/274832

Bartosiewicz, L., Gillis, R., Girdland Flink, L., Evin, A., Cucchi, T., Hoelzel, R., Vidarsdottir, U., Dobney, K., Larson, G., Schoop, U.-D. (2013): Chalcolithic pig remains from Çamlıbel Tarlası, Central Anatolia. - In: DeCupere, B., Linseele, V., Hamilton-Dyer, S. (eds), Ancient Near Eastern Studies: Archaeozoology of the Near East X. Proceedings of the Tenth International Symposium on the Archaeozoology of South-Western Asia and Adjacent Areas. Ancient Near Eastern Studies, Supplement series, 44: 101-120. 
Bilgin, M., Joniak, P., Mayda, S., Göktaş, F., Kaya, T., Peláez Campomanes, P., van den Hoek Ostende, L. (2019): Sabuncubeli too, Bornova, a second micromammal assemblage from the Sabuncubeli section (early Miocene, Western Anatolia). - Palaeobiodiversity and Palaeoenvironments, 99: 655-671. https://doi.org/10.1007/s12549-019-00395-2

de Bruijn, H., Mayda, S., van den Hoek Ostende, L., Kaya, T., Saraç, G. (2006): Small mammals from the Early Miocene of Sabuncubeli (Manisa, S.W. Anatolia, Turkey). - Beiträge zur Paläontologie, 30: 57-87.

Fortelius, M., Bernor, R. (1990): A provisional systematic assessment of the Miocene Suoidea from Pasalar, Turkey. - Journal of Human Evolution, 19: 509-528. https://doi.org/10.1016/0047-2484(90)90062-G

Fortelius, M., Van der Made, J., Bernor, R. (1996): A new listriodont suid, Bunolistriodon meidamon sp. nov., from the Middle Miocene of Anatolia. - Journal of Vertebrate Paleontology, 16(1): 149-164. https://doi.org/10.1080/02724634.1996.10011293

Geraads, D., Kaya, T., Mayda, S. (2005): Late Miocene large mammals from Yulafli, Thrace Region, Turkey, and their biogeographic implications. - Acta Palaeontologica Polonica, 50: 523-544.

Gervais, P. (1859): Zoologie et Paléontologie françaises $\left(2^{\text {nd }}\right.$ ed.). - Bertrand, Paris, 544 pp.

Ginsburg, L. (1974): Les Tayassuidés des Phosphorites du Quercy. - Palaeovertebrata, 6: 55-85.

Gray, J. E. (1821): On the natural arrangement of vertebrose animals. - London Medical Repository, 15(1): 296-310.

Hilgen, F. J., Lourens, L. J., Van Dam, J. A. (2012): The Neogene Period. - In: Gradstein, F. M., Ogg, J. G., Schmitz, M. D., Ogg, G. M. (eds), The Geologic Time Scale. Elsevier, Amsterdam, Boston, Heidelberg, London, New York, Oxford, Paris, San Diego, San Francisco, Singapore, Sidney, Tokyo, pp. 923-978. https://doi.org/10.1016/B978-0-444-59425-9.00029-9

Hünermann, K. A. (1968): Die Suidae (Mammalia, Artiodactyla) aus den Dinotheriensanden (Unterpliozän $=$ Pont) Rheinhessens (Südwestdeutschland). Schweizerische Paläontologische Abhandlungen, 86: $1-96$.

Hünermann, K. A. (1975): Die Suidae aus dem Türkischen Neogen. - In: Sickenberg, O. (ed.), Die Gliederung des Höheren Jungtertiärs und Altquartärs in der Türkei nach Vertebraten und ihre Bedeutung für die internationale Neogen-Stratigraphie. Geologisches Jahrbuch, B, 15: 153-156.

Hunter, J. P., Fortelius, M. (1994): Comparative dental occlusal morphology, facet development, and microwear in two sympatric species of Listriodon (Mammalia: Suidae) from the Middle Miocene of western Anatolia (Turkey). - Journal of Vertebrate Paleontology, 14(1): $105-126$.

https://doi.org/10.1080/02724634.1994.10011541

ICZN [International Commission on Zoological Nomenclature] (1999): International Code of Zoological Nomenclature $\left(4^{\text {th }}\right.$ ed.). - International Trust for Zoological Nomenclature, London, XXIX + 306 pp.

Kaya, O., Ünay, E., Göktaş, F., Saraç, G. (2007): Early Miocene stratigraphy and tectonics of central west
Anatolia, Turkey: implications for the evolution of eastern Aegean areas. - Geological Journal, 42(1): 85-109.

https://doi.org/10.1002/gj.1071

Kostopoulos, D. S., Sen, S. (2016): Suidae, Tragulidae, Giraffidae, and Bovidae. - In: Sen, S. (ed.), Late Miocene mammal locality of Küçükçekmece, European Turkey. Geodiversitas, 38(2): 273-298.

https://doi.org/10.5252/g2016n2a8

Liu Liping, Fortelius, M., Pickford, M. (2002): New fossil Suidae from Shanwang, Shandong, China. - Journal of Vertebrate Paleontology, 22: 152-163.

https://doi.org/10.1671/0272-4634(2002)022[0152:NFS FSS]2.0.CO;2

Liu Liping, Kostopoulos, D. S., Fortelius, M. (2005): Suidae (Mammalia, Artiodactyla) from the late Miocene of Akkasdagi, Turkey. - In: Sen, S. (ed.), Geology, mammals and environments at Akkasdag1, late Miocene of Central Anatolia. Geodiversitas, 27(4): 715-733.

Malik, A., Nafiz, H. (1933): Küçükçekmece fosil fikrali hayvanlar mecmuasi / Vertébrés fossiles de Küçükçekmece. - Istanbul Darülfünunu Geologie Enstitüsü nesriyatindan [Publication de l'Institut de géologie de l'Université de Istanbul], 8: 1-119. (in Turkish and French)

Mayda, S. (2010): The early Miocene Carnivores from Sabuncubeli, Turkey. - In: Chatzipetros, A., Melfos, V., Marchev, P., Lakova, O. (eds), Abstracts Volume, XIX Congress of the Carpathian-Balkan Geological Association, Thessaloniki, Greece, 23-26 September 2010. Geologica Balcanica, 39(1-2): 246-247.

Mayda, S., Rössner, G. (2007): Oldest Tragulidae record from Turkey and dispersal of Tragulidae in Miocene. In: 60th Turkish Geology Symposium, April 16-22, 2007, Ankara, Turkey, 3 pp. [unpaginated].

Mein, P. (1989): Updating of MN zones. - In: Fahlbusch, V., Mein, P., Lindsay, E. H. (eds), European Neogene mammal chronology. Plenum Press, New York, pp. 73-90. https://doi.org/10.1007/978-1-4899-2513-8_6

Meyer, H. von (1834): Die fossilen Zähne und Knochen und ihre Ablagerung in der Gegend von Georgensgmünd in Bayern. - Abhandlungen der Senckenbergischen Naturforschenden Gesellschaft, 8: 1-126. https://doi.org/10.5962/bhl.title.25040

Meyer, H. von (1846): [Mitteilungen an Prof. Bronn]. Neues Jahrbuch für Mineralogie, Geognosie, Geologie und Petrefakten-Kunde, 1846: 462-476. (part about "tertiäre Wirbelthiere zu la-Chaux-de-Fonds, theils von neuen Geschlechtern" on pp. 464-470)

Morales, J., Mayda, S., Valenciano, A., DeMiguel, D., Kaya, T. (2019): A new lophocyonid, Izmirictis cani gen. et sp. nov. (Carnivora: Mammalia) from the lower Miocene of Turkey. - Journal of Systematic Palaeontology, 17(16): 1127-1138. https://doi.org/10.1080/14772019.2018.1529000

Orliac, M. J., Karadenizli, L., Antoine, P.-O., Sen, S. (2015): Small hyotheriine suids (Mammalia, Artiodactyla) from the late early Miocene of Turkey and a short overview of early Miocene small suoids in the Old World. Palaeontologia Electronica, 18.2.30A: 1-18. https://doi.org/10.26879/547

Owen, R. (1848): Description of teeth and portions of jaws of two extinct anthracotheroid quadrupeds (Hyopotamus 
vectianus and $H$. bovinus) discovered by the Marchioness of Hastings in the Eocene deposits on the N.W. coast of the Isle of Wight. - Quarterly Journal of the Geological Society of London, 4: 104-141.

https://doi.org/10.1144/GSL.JGS.1848.004.01-02.21

Ozansoy, F. (1957): Positions stratigraphiques des formations continentales du Tertiaire de l'Eurasie au point de vue de la chronologie nord-américaine. - Maden Tetkik ve Arama Bulletin, 49: 11-28.

Ozansoy, F. (1965): Étude des gisements continentaux et des Mammifères du Cénozoïque de Turquie. - Mémoires de la Société géologique de France, N. S., 44: 1-91.

Pickford, M. (1981): Preliminary Miocene Mammalian biostratigraphy for Western Kenya. - Journal of Human Evolution, 10: 73-97. https://doi.org/10.1016/S0047-2484(81)80026-7

Pickford, M. (1986): A revision of the Miocene Suidae and Tayassuidae of Africa. - Tertiary Research Special Paper, 7: 1-83.

Pickford, M. (1988): Un étrange Suidé nain du Néogène supérieur de Langebaanweg (Afrique du Sud). - Annales de Paléontologie, 74: 229-249.

Pickford, M. (1993): Old World Suoid systematics, phylogeny, biogeography and biostratigraphy. Paleontologia i Evolució, 26-27: 237-269.

Pickford, M. (1995): Suidae (Mammalia, Artiodactyla) from the early Middle Miocene of Arrisdrift, Namibia: Namachoerus (gen. nov.) moruoroti, and Nguruwe kijivium. - Comptes Rendus de l'Académie des Sciences, Paris, Séries II a, 320: 319-326.

Pickford, M. (2016a): Hippopotamodon erymanthius (Suidae, Mammalia) from Mahmutgazi, Denizli-Çal Basin, Turkey. - Fossil Imprint, 72: 183-201. https://doi.org/10.14446/FI.2016.183

Pickford, M. (2016b): Revision of European Hyotheriinae (Suidae) and Doliochoeridae. - Münchner Geowissenschaftliche Abhandlungen, Reihe A: Geologie und Paläontologie, 44: 1-270.

Pickford, M. (2017): Revision of "peccary-like" Suoidea (Artiodactyla: Mammalia) from the Neogene of the Old World. - Münchner Geowissenschaftliche Abhandlungen, Reihe A: Geologie und Paläontologie, 46: 1-144.

Pickford, M. (2018a): New evidence concerning relationships within Artiodactyla, Mammalia: radicular morphology of the dp/4. - Historical Biology, 30(1-2): 119-136. [published on-line on 8th May 2017] https://doi.org/10.1080/08912963.2017.1320398

Pickford, M. (2018b): New data on Early Miocene Palaeochoerus typus and the origins of the family Suidae (Mammalia). - Revue de Paléobiologie, 37(2): 519-532.

Pickford, M., Ertürk, C. (1979): Suidae and Tayassuidae from Turkey. - Bulletin of the Geological Society of Turkey, 22: 141-154.

Pickford, M., Morales, J. (2003): New Listriodontinae (Suidae, Mammalia) from Europe and a review of listriodont evolution, biostratigraphy and biogeography. - Geodiversitas, 25(2): 347-404.

Pickford, M., Morales, J. (2016): Basal Middle Miocene Listriodontinae (Suidae, Artiodactyla) from Madrid, Spain. - Spanish Journal of Palaeontology, 31(2): 369-405. https://doi.org/10.7203/sjp.31.2.17162
Pickford, M., Moyà-Solà, S. (1995): Eurolistriodon gen. nov. (Suoidea, Mammalia) from Els Casots, early Middle Miocene, Spain. - Proceedings of the Koninklijke Nederlandse Akademie van Wetenschappen, 98: 343-360.

Pickford, M., Tsujikawa, H. (2019): Revision of African Kubanochoerinae (Suidae: Mammalia) with descriptions of new fossils from the Middle Miocene Aka Aiteputh Formation, Nachola, Kenya. - Münchner Geowissenschaftliche Abhandlungen, Reihe A: Geologie und Paläontologie, 48: 1-105.

Pomel, A. (1847): Note sur des animaux fossiles découverts dans le département de l'Allier (Addition au Mémoire sur la géologie paléontologique, etc. Bull 2è série, t. III, p. 353). - Bulletin de la Société géologique de France, Paris, 2ème série, 4: 378-396.

Pomel, A. (1848): Observations paléontologiques sur les hippopotames et les cochons. - Bibliothèque universelle de Genève et Archives des Sciences Physiques et Naturelles, 8: 155-162.

Senyürek, M. (1951): Gökdere (Elmadagi) Fauna'sina dair bir not [A note on the Gökdere (Elmadagi) Fauna]. - Ankara Üniversitesi Dil ve Tarih-Coğrafya Fakültesi Dergisi [Ankara University Journal of the Faculty of Languages and History-Geography], 9: 63-73. (in Turkish)

Senyürek, M. (1952): A study of the Pontian fauna of Gökdere (Elmadagi), south-east of Ankara. - Türk Tarih Kurumu Basimevi, 16(64): 451-492.

Stehlin, H. G. (1899): Ueber die Geschichte des SuidenGebisses. ErsterTeil.-Abhandlungen der Schweizerischen paläontologischen Gesellschaft, 26: 1-336.

Thenius, E. (1949): Über die Säugetierfauna aus dem Unterpliozän von Ilhan bei Ankara (Türkei). Sitzungsberichte der Österreichischen Akademie der Wissenschaften, mathematisch-naturwissenschaftliche Klasse, Abt. I, 158: 656-661.

Tschachtli, B. (1942): Küçük Yozgat civarında bulunan memeli hayvanat fosilleri / Fossile Saeugetiere aus der Gegend von Küçükyozgat (östlich Ankara). - Maden Tetkik ve Arama Enstitusu Dergisi, 2(27): 322-327. (in Turkish and German)

Van der Made, J. (1996): Listriodontinae (Suidae, Mammalia), their evolution, systematics and distribution in time and space. - Contributions to Tertiary and Quaternary Geology, 33: 3-254.

Van der Made, J. (2003): Suoidea, Artiodactyla. - In: Fortelius, M., Kappelman, J., Sen, S., Bernor, R. (eds), Geology and Paleontology of the Sinap Formation, Turkey. Columbia University Press, New York, pp. 308-327.

Van der Made, J., Gülec, E., Erkman, A. (2013): Microstonyx (Suidae, Artiodactyla) from the Upper Miocene of Hayranli-Haliminhani, Turkey. - Turkish Journal of Zoology, 37: 106-122.

Van der Made, J., Tuna, V. (1999): A tetraconodontine pig from the Upper Miocene of Turkey. - Transactions of the Royal Society of Edinburgh Earth Sciences, 89: 227-230. https://doi.org/10.1017/S0263593300007148

Yakut, H. (2012): Anadolu Miyosen Dönem Suidleri [Miocene Epoch Suids in Anatolia]. - Mehmet Akif Ersoy Üniversitesi Sosyal Bilimler Enstitüsü Dergisi, 4(6): 35-51. (in Turkish) 